\title{
The Cohesiveness of Veiled Women's Da'wah Communication Group
}

\author{
Arianto \\ Universitas Hasanuddin Makasar, Indonesia \\ *email.arianto@unhas.ac.id
}

\begin{abstract}
The purpose of this study was to understand the cohesiveness of the da'wah communication of veiled women in the guidance of Islamic teachings. It closely relates the perception of cohesiveness to the sensation component of the collectivity of group members. For example, communication, collectivity, cooperation, common goals, and interdependence of group members. The research method used is descriptive qualitative, case study research type. The subject of the study were 6 female informants, representatives of Hasanuddin University students who wore a veil in their daily life. The collected data were analyzed inductively. The result that the cohesiveness of veiled women's dakwah communication includes aspects of interpersonal communication cohesiveness, commitment cohesiveness, and cohesiveness aspects of achieving common goals. This aspect of cohesiveness focuses his life on life after death. This also makes them have a strong, cooperative, and sincere character together. The cohesiveness of da'wah communication to continually learn with Islam. It veils the research implication of the cohesiveness of women on equality for preaching, da'wah is the purpose of life so it unites them in da'wah efforts.
\end{abstract}

Keywords: Cohesiveness; veiledwWoman; da'wah communication.

\begin{abstract}
ABSTRAK
Tujuan penelitian ini adalah untuk memahami kohesifitas komunikasi dakwah kelompok wanita bercadar dalam tuntunan ajaran Islam. Persepsi kohesifias sangat terkait dengan komponen sensasi kolektifitas anggota kelompok. Seperti, komunikasi, kolektifitas, kerjasama, tujuan bersama, dan saling ketergantungan anggota kelompok. Metode penelitian yang digunakan adalah kualitatif deskriptif, tipe penelitian studi kasus (case study). Subjek penelitian wanita bercadar sebanyak 6 informan, representatif mahasiswi Universitas Hasanuddin yang mengenakan cadar dalam keseharian. Selanjutnya, data yang terkumpul dianalisis secara induktif. Hasil penelitian bahwa kohesivitas komunikasi dakwah wanita bercadar meliputi aspek kohesifitas berkomunikasi interpersonal, aspek kohesifitas berkomitmen, dan aspek kohesifitas pencapaian tujuan bersama. Aspek kohesifitas ini memfokuskankehidupannya untuk kehidupan sesudah mati. Hal ini juga menjadikan mereka memiliki karakter bersama yang kuat, bekerjsama, dan ikhlas. Kohesifitas komunikasi dakwah dalam upaya keinginan belajar bersama Islam secara terus menerus. Impilikasi penelitian kohesifitas wanita bercadar pada kesamaaan untuk berdakwah, dakwah adalah tujuan hidup sehingga mereka disatukan dalam usaha dakwah. Kata kunci: Kohesifitas; wanita bercadar; komunikasi dakwah.
\end{abstract}

Received: Agustus 2020. Accepted: Oktober 2020. Published: Desember 2020. 


\section{INTRODUCTION}

Da'wah communication is an important part of life. On the latest developments. Da'wah communication is an effective way of conveying religious messages for da'wah. Da'wah communication can be done as exclamations, giving examples of noble morals, and activities that are beneficial for every human being (Maghfiroh, 2016).

The law of da'wah activities is mandatory for every Muslim. Most Indonesians are Muslim, must carry out or do it continuously. Da'wah communication has the goal of changing human behavior based on correct knowledge and attitudes, namely to bring people to serve Allah SWT in total.

Da'wah communication is a communication model that has special characteristics, both in terms of materials, methods and communicators. To find the right solution and model, it needs a special study to find the root of the problem related to dakwah communication. Communication of Islamic da'wah is carried out as actualization of faith (theological) which is manifested in a system of activities between believers. This da'wah communication activity can be carried out individually, in groups or in larger numbers (Maghfiroh, 2016).

The veiled woman is an advanced female version of the veil. Women in veils are the personal manifestations of women in doing da'wah activities, da'wah communication activities in togetherness in their groups. This is illustrated by women who add a face covering so that only their eyes are visible, it must cover even the palms. If a woman with a headscarf also requires wearing a long dress, then veiling is followed by the habit of wearing a robe (not pants), long and wide skirts, and usually all black or dark-colored accessories.

The group of veiled (and veiled) women has only gained public attention in recent years. It relates this to the new order government policy that had banned the use of the headscarf in schools and in the workspace. After the reformation of the headscarf gained its freedom as an identity for Muslim women, although there is still controversy about the meaning of the use of the veil. The veil is an advanced version of the use of the headscarf, in the study of Islamic interpretation itself the arguments that regulate if the use of the veil is obligatory.

Veiled women in group daily activities and intensively communicate in groups. I do regularly this to influence, behave and act in order to achieve 
the realization of Islamic teachings in all aspects of life by using certain methods. Although, the acceptance of Muslim women with headscarves requires a long process, considering that we consider the veil not part of Indonesian culture, especially in a tropical climate. Even though they are veiled, there is a continuation of the use of the veil as a guide for Islamic da'wah, especially for women and girls. For some Muslims, veiling is a logical consequence of a more intense learning process about women in carrying out the guidance of Islamic teachings. However, the use of the veil carries greater consequences for rejection than the veil. Besides the problem of stigma attached to veiled women, namely fundamental (radical) Islamic currents, related to terrorism, the veil is now also facing technical resistance, especially those related to public services (Lintang Latri, 2016).

The results of the research on public perceptions of veiled women are very negative, ostracized or even reject their existence and it does not consider them in society (Nursalam \& Syarifuddin, 2017). There is a different view that the Niqab or veil is only part of the clothes worn by some Arab women from pre-Islamic and later. There is no specific commandment regarding this garment, neither obligation nor extinction. This issue is interesting, because we can propose various points of view to analyze it. Based on the viewpoint of fiqh and trying to understand it by seeing it as a sociological symptom of Muslim society. The niqab is a type of clothing worn by some women during the Jahiliyyah era. This clothing style lasted until Islam. Prophet Muhammad SAW, did not question the style of clothing, but did not oblige, appealed to or gave the niqab to women (Sudirman, 2019). As explained, the findings of previous research results, that their motivation to veil is a form of religious obedience and the desire to avoid sexual objectification. Readiness to face stigma such as being fanatical, a member of a terrorist group, and being avoided by those around him. We can classify the strategies for dealing with stigma taken by participants into two, namely internal strategies by ignoring and tolerating the negative views of the surrounding community, and external strategies through providing explanations as clarification and engaging in joint activities with the surrounding community (Rahman \& Syafiq, 2017).

Apart from this, women who wear hijab in Indonesia present themselves very diversely. For example, it is comfortable with only use the hijab and there are also those who choose to cover their genitals to the feet, besides there are women who are used to using the hijab to cover their chest or wearing a veil. We need not debate this diversity in a Muslim 
majority country. The stigma of veiled Muslim women arises because society is not used to seeing people wearing veils. As revealed in the research results of Jaspere et al. (2012) which states that Muslim women in the United States wear the hijab and veil not only as a symbol of religious identity but also as a symbol of freedom from sexual objectification, and pride to appear different (Jasperse et al., 2012).

Whereas wearing a veil or covering one's face for women is Islamic teaching, based on the arguments of the Qur'an, authentic hadiths and the application of the companions of the Prophet Sallallahu'alaihi Wasallam and the scholars who followed them. As according to the Hanafi school of thought, a woman's face is not aural, but wearing the veil is sunnah (recommended) and becomes mandatory if they fear it it will cause slander (Purnama, 2011).

The form of da'wah messages that convey true divine values must be understood as a manifestation of the values of tolerance, brotherhood, and as a form of an internal dialogue of religious communities and an effort to build awareness for the creation of harmony between religious believers. Building the nuances of harmonization is a hope for a pluralistic country, but to make it happen requires an effort and an effective communication pattern (Burhanuddin, 2019).

The da'wah communication of veiled women in their groups contains thoughts, arguments, views, calls or invitations or the use of other symbols for conversion or attempts to change situations to a better and perfect situation in a context. It manifests this through the wearing of the veil (veil) which is a form of their obedience to Allah's commands. In addition, we use the veil as an extra protection in their social space, including in cities that have gone to their metropolitan areas, where the majority do not use veils. The interactions carried out by veiled Muslim women in their social space and positive things that are done make the community have a positive view of veiled Muslim women. However, not all societies consider veiled Muslim women negatively. Women in the veil have the belief that using the veil adds a new attribute in oneself that must be implemented into daily activities, namely piety (Lintang Latri, 2016). Its presence gave birth to religious values through da'wah communication in maintaining religious continuity together and in groups.

Building good da'wah communication patterns can prevent religious conflicts in the community. Da'wah messages that convey true divine values must be understood as a manifestation of the values of tolerance, 
brotherhood, and as a form of an internal dialogue of religious communities and an effort to build awareness for the creation of harmony between religious believers. Building a nuance of harmonization is a hope for a pluralistic country, but to make it happen requires an effort and an effective communication pattern (Burhanuddin, 2019).

For Muslim women, the decision to use the veil is not significantly influenced by age, and academic education, but because of the openness of access to study Islam intensively and access to the veil user community. For example, an informal group of students who are self-conscious on the Hasanuddin University campus. They wear the veil, wearing the veil is part of total obedience to Allah SWT and efforts to protect Muslim women from negative behavior. One improvement in the quality of life for a woman is to carry out the source commandment, which is to cover the aura.

Veiled women in building communication and interaction are often only with each other, regularly gather, socialize, and communicate with each other in groups, especially in the moments before prayer 5 (five) times in mosques on campus. In the process of interaction, exclusivity, and closeness of groups of veiled Muslim women can hinder the socialization process. It is as if they are only hanging out with their own group, even though all communities must be able to get along with anyone, whether they are students who don't wear the veil, apart from the necessity of interacting and communicating with other people.

There were groups of veiled women in the Hasanuddin University campus environment, grouped together, having their own attachment or attraction to them, communicating with each other in order to fulfill learning goals and mutual motivation. Routine together and work together in groups. The relationship that occurs creates cohesiveness between group members. Cohesiveness is felt because they have a level of interest and belief in the group's success, carrying out the syar'i orders. Group cohesiveness is the emotional attraction of fellow members of the work group where there is a sense of mutual help and jointly support each other to remain in the group to achieve one goal. The self-concept of a woman in the city of Makassar is influenced by religious self-concept. Knowledge of religious laws and guidance is the major factor that encourages informants to decide to wear the veil. In addition, peer relations of the same sex such as female peers both on campus and at work, peer relations of the opposite sex and physical appearance also contribute to the formation of 
the self-concept of veiled Muslim women in Makassar City (Puspanegara, 2016).

The phenomenon is interesting to study, the cohesiveness of the veiled student group, when they establish relationships of personal needs and values, cooperation between group members, and view the group as more beneficial than other groups. Social grouping is part of the human relationship with society. Groups have strength and culture, different from themselves. Groups contain characteristics that are common to every other group, but they also have characteristics that are unique to the group in question (Jarvis, 2006).

The veiled student group is part of a group that has the same goals for its members, mutual benefits for members, social structure, group processes, and self-categorization. A group comprises a set of individuals who interact, depend on and help one another. This refers to social cohesiveness, where team members like and receive personal satisfaction from each other's presence. The power of group communication from this.

It shows chastity as communication between group members, they usually spend time together. Members express their opinions and suggestions. Group members are usually also enthusiastic about what is being communicated and will sacrifice their personal interests for the benefit of the group. All of this shows the unity, closeness, and mutual attraction of group members.

Group cohesiveness refers to the degree to which it attracts group members to each other and feel part of the group members. Group membership is usually enthusiastic about what I do and will sacrifice personal interests from the interests of the group. Each member will assume responsibility for activities in order to fulfill their obligations. This shows the unity, interest, and closeness of group members which is the definition of group cohesiveness (Qomaria \& Musadieq, 2015).

The following positive strengths are the extent to which a group interacts effectively and in harmony. Meanwhile, group cohesiveness is influenced by negative forces which causes its members not to dare to leave the group, even though they feel dissatisfied. Sometimes people stay in a group because the costs they will incur if they leave the group are very high or because other options are not available (Retno Ristiasih Utami, 2016).

Previous research on the Jamaah Bligh group made this group more compact and familiar in preaching. It measures the cohesiveness of the Tablighi Jamaat group from the four dimensions of cohesiveness, namely 
social unity, unity in groups, attractiveness, and group cooperation. They base the cohesiveness of the group on the similarity to preach together until death. They base the cohesiveness of the Tablighi Jamaat group on the fact that da'wah is the goal of life so it unites them in the proselytizing effort (Ikbar et al., 2019).

It bases group cohesiveness on the beliefs and perceptions of each group member. The beliefs held by members, according to Jarvis (2006) as the basis for group integration. Highly cohesive groups are more likely to be united and committed to success than groups with low cohesion, such as a cohesive team where players are united on a common goal, often spending time together or sharing common interests outside of their sport of choice, social cohesiveness (Kebaili et al., 2015). Group cohesiveness refers to the dynamic process of groups that stick together and unite in pursuit of their goals for the satisfaction of the affective needs of each group member, group members create a sense of individual and group cohesion. For example, the results of Iskandar's (2019) study revealed that to increase employee productivity, it can be done with group cohesiveness, that; (1) there is a direct effect of group cohesiveness on productivity, and ((2) there is a direct effect of group cohesiveness on job satisfaction (Iman Iskandar, 2020).

The research concept of veiled student group cohesiveness has attracted ongoing social psychologists. Based on interest, might create cohesiveness. The stronger the interest, the stronger the cohesiveness of group members. Apart from that, physical and psychological closeness among group members can also affect the cohesiveness of group members. As expressed that group cohesion as., "group cohesion as "the tendency for a group to stick together and remain united in the pursuit of its instrumental objectives and/or for the satisfaction of member affective needs" (Harrison et al., 2003).

A group that achieves its goals has a psychological impact on its members, one of which is that togetherness and member cohesion increases. Likewise, the loyalty of veiled students in groups. It is not every member who has a strong identification, so that the group has strong cohesiveness.

Referring to this, the researcher focused this research on analyzing the cohesiveness of a group of veiled students who remained together and united in pursuing their instrumental goals. The veiled student group has a firm belief to get the satisfaction of their affective needs as women who 
obey the guidance of Islam, like the results of Iskandar's (2013) research that veiled women are based on their understanding of the real hijab. Veiled women interpret the veil as obedience and guidance and orders from Allah Swt (Amalia et al., 2013).

A form of multidimensional construction comprising aspects of dakwah and social tasks, and involving a dual process of integration into groups and with other group members, enhancing the dynamics and psychological state of the group. Differences in aspects of the relationship between cohesion and components, such as satisfaction, mood role ambiguity, and cognitive variables. Like the findings of the research results, the relationship between commitment to organization and group cohesiveness and there is no difference in group cohesiveness between the educative group and the administrative staff group so it does not accept the hypothesis in this study (Purwaningtyastuti et al., 2012).

The results of other research on motor community cohesiveness show that there is a role for interpersonal communication on group cohesiveness in the motor community. The higher the interpersonal communication in the motor community, the higher the group cohesiveness in the motor community. Conversely, if the interpersonal communication in the motor community is low, the group cohesiveness in the motor community is low (Sari et al., 2017). Other research relates to the Bligh group conducting Islamic da'wah communication activities. The tradition of preaching outside space (khuruj and khillah) and how to invite people to do good (Jaulah)(Effendy \& Rustandi, 2020).

The cohesiveness of the da'wah communication of a group of veiled students is interesting to study because the way they carry out Allah's commands differs from Muslim women. The intensity of their da'wah communication is marked by the "courage" to defend their opinion without being afraid and afraid against differences of opinion where they live among those who are minimally veiled. The concept of representation of Muslim women is part of the construction of Islam as a group identity, the process of intervention in social change, including interventions framed by da'wah (Nurjuman et al., 2018).

The activities of the da'wah community of students in the veil, such as sunnah study, gathering, rihlah, ukhuwah, training, and online marketing. The conception of these activities makes dakwah communication flexible, casual but still not excessive to maintain the comfort of all group members.

The purpose of this study was to understand the cohesiveness of the 
da'wah communication of the veiled student group in the guidance of Islamic teachings. The perception of cohesiveness is closely related to the components of the sensation of collectivity of members of this group, such as collectivity, cooperation, common goals, and interdependence of each group member, through interactions in their social space and positive things that are done to achieve that they are part of society having a positive view of veiled woman.

This study analyzes the cohesiveness of the da'wah communication of a group of veiled students. The subjects in this study were female students who wore a veil, actively gathered and grouped with veiled women at Hasanuddin University. The object of the study was the cohesiveness of the student group or veiled women who felt togetherness, cooperation, and connectedness of relationships and were mutually dependent on communicating da'wah among them. as part of a group.

This research method uses a descriptive qualitative approach, type of case study research (case study), primary data collection techniques using in-depth interview instruments and non-participant observation. The closure of this group of veiled women so that the researcher involved colleagues in helping to collect data from 6 female student informants who wore veils in their daily lives continuously for approximately 11 months and over, between January-February 2020, and secondary data using scientific literature reviews from various journals. research in relation to the cohesiveness of dakwah communication dynamics in a group of veiled women. Furthermore, the collected data were analyzed inductively.

\section{RESULTS AND DISCUSSION}

\section{Analysis of the Cohesiveness of the Veiled Women's}

The results of research on student informants at Hasanuddin University, especially those wearing veils, were about the cohesiveness of da'wah communication in their communities. Among the communication arrangements that can be implemented in da'wah, namely the order of communication between individuals, groups and the public. The purpose of da'wah communication is to hope for a change or formation of attitudes or behavior under the teachings of the Al-Qur'an and hadith as a source of Islamic teachings.

For groups that have high cohesiveness, each member of the group will also have a high commitment in conducting dakwah communication. Groups that have a low level of cohesiveness will not be attracted to each 
other to carry out dakwah communication. Cohesiveness depends on the level of individual interest each member of the group has. The more members of the group feel attracted to and the more they agree with the target group, the more cohesive the group will be.

The results of the study found that the students wearing the veil were a form of their obedience to Allah's commands. Da'wah communication messages are conveyed through the way they wear the veil. The form of symbolizing the message of da'wah as extra protection of the genitals in their social space, among the domination of their friends, the majority do not wear the veil. The cohesiveness of veiled student da'wah communication comes from shared knowledge, attitudes and behavior patterns, mutual interest in attitudes, values, and collective behavior in carrying out Islamic da'wah messages.

In this context, groups of students and veiled women are a group of da'wah which in their daily da'wah activities are often involved in communicating with each other, such as soliciting Muslims, eating together, studying together and worshiping together. This is a sense of community and shows cohesiveness within the group. The following is a description of the research results based on three aspects of the cohesiveness of the da'wah communication of the veiled women group, namely.

\section{Aspects of Interpersonal Communication Cohesiveness.}

The concept of Islamic studies that is carried out together causes the intensity of communication to be established and cohesiveness in this group. Good and intensive communication between veiled female members can increase group cohesiveness. The ability to communicate and interact is very important in a group life. Communication within the group becomes the central point in creating a cohesive situation and establishing continuous communication between members. A special form of human communication, one of which is interpersonal communication.

We can see the cohesiveness aspect of interpersonal communication from the cohesiveness and solidarity that exists between these veiled women in interpersonal communication in a group. The cohesive aspect of communicating dakwah refers to a state of mutual liking and attraction among members where members are united and have a desire to maintain positive relationships, and there is a shared feeling in implementing Islamic sharia. The results of observations in the field, veiled women have never experienced clumsiness in interpersonal communication. They base this on 
the concept of ukhuwah Islamiya, where fellow Muslims are brothers.

A positive attitude refers to the cohesiveness of communicating interpersonal together. This aspect of cohesiveness is cultivated in veiled women who have a positive attitude towards themselves and positive feelings for the communication situation among veiled women in an effective interactive manner. Positive reinforcement is generally in the form of praise or appreciation, and consists of behaviors that are usually expected. This positive encouragement supports the veiled woman's personal image and makes her feel better.

As conveyed by an HDI informant, a student who wore a veil for about 1 year at the FISIP, explained the reason for the first time taking the initiative to wear a face veil because wearing a veil is an Islamic law which only creates two differences of opinion among scholars, namely mandatory and sunnah:

"Togetherness and regularly meet in Islamic studies at the campus mosque, especially the themes of us women in attitude and behavior, so we avoid judgments about negative things, so it's nice to join and discuss together the opportunity to get rewarded why don't we do this. A form of our piety, and this is also a form of our efforts to carry out religious propagation or propagation, this makes us very close, supportive, and motivated, so it is because we always communicate with each other," (Interview 12 June 2019)

Da'wah communication is carried out by veiled students in their social space, participatory, motivational and positive things that are done make them have a positive view as obedient women in a close togetherness between them. The opinion of the DIM informant was that FISIP students were close friends with HDI informants. She currently wears a large hijab which reaches up to her knees.

It describes this aspect of interpersonal communication cohesiveness as the attractiveness of individuals to their groups and their desire to collaborate in the group in the future. Cohesiveness has important implications for group performance and interpersonal interactions. A highly cohesive group displays a more positive relationship among members and can increase flexibility and productivity. Yoo and Alavi's (2001) research highlighted that the increase in group cohesiveness was mainly because of an increase in their interpersonal communication (Harrison et al., 2003).

A form of meaningful human action through a process of 
communication between veiled women; encompasses a process involving interpretation, thinking, and deliberation. Social action as all human behavior when and if the individual gives a subjective meaning to that behavior.

They routinely take part in studies with veiled student associations where the contents of the lecture or study talk about syari'a, arguments or hadiths which presumably explain the halal haram of women taking action. As DIM put it:

"We have interpersonal communication together based on shared views and we often discuss matters of piety, for example, if a woman when she leaves the house, she beautifies herself, so how then can we avoid or minimize ourselves so that there is little chance that syaiton does not. can disturb us". (Interview 12 June 2019)

The cohesiveness of da'wah communication through the application process of devotion to Allah SWT, collaboration, pride of the group committed to carry out all His commands including covering the entire body including the face. In addition, the dominance of the individual's ability to prioritize group success over individual goals and foster strong trust and communication between group members. For example, personality traits can influence perceptions of social cohesion. Undergraduate students at Mid-Atlantic University are group members working together in groups influenced by the personality and communicative nature of the experiences in the group (Ahmed et al., 2012).

The cohesiveness of the da'wah communication in their group is routine, empathetic, cooperative, committed and proud of being alone as part of the mutual scope of their various knowledge, attitudes and experiences as a person who obeys the commandments of Allah SWT. Another thing, it was found that each of them had high commitment, cooperation, through communication of da'wah messages and had goals in the group dominated by cooperation, relationships and not competition. Without communication, there would be no coexistence that formed their cohesiveness in communicating. This group of veiled women is considered to be the family of the world and the hereafter for every member. The trust that results from communication results in greater social cohesion, then contributes to their feelings, and can then successfully complete the task (Ahmed et al., 2012). Veiled women often limit themselves so as not to be too conspicuous in their social interactions. This refers to the dimension of 
the direction of cohesiveness that cohesiveness can exist between the various dimensions in the hierarchy. This cohesiveness is not only relevant to individuals and small groups but is equally relevant across groups within the larger collective and perhaps outside the group. Thus, cohesiveness can be conceptualized as a multilevel construction.

\section{Aspects of Committed Cohesiveness}

Veiled women have an aspect of cohesiveness to commit together. This aspect of cohesiveness for communicating da'wah is as a strong desire, and an interest in manipulating the message of da'wah through carrying out Islamic worship through the message of da'wah and this gives rise to a feeling of involvement and strength of veiled women for the achievement of group goals.

We can see their cohesiveness from the encouragement of members to stay together in the group compared to the urge to push members out of the group. Joining a group gives veiled women a sense of belonging and feeling together. This has a beneficial impact because veiled women have a good commitment which will cause achievement and achievement of common goals in a group cohesiveness bond. Commitment to the success of common goals and the desire to listen, meet and follow the suggestions or opinions of fellow members increases.

Another informant's explanation, MS student wearing a veil at the Faculty of Engineering, routinely takes part in studies with other veiled student groups, at the campus mosque. The explanation that we have a strong desire, commitment and pride to love group members naturally with rational and realistic goals to promote common goals, is:

"We have a high desire and commitment that I veil us to block the view of people who are haram to see us, our pride as women, we all work together for this." (Interview 13 June 2019)

We cannot separate the decision to keep wearing the veil of all informants from the influence of other fellow students in a group. Wearing the veil is a participant's decision based on what they already understand in religion. The act of not thinking about the negative attitudes of others, because for him showing that patience can bring rewards and togetherness in understanding religion is a form of spiritual attachment and cooperation in achieving common goals, a view of cohesiveness between them.

Their cohesiveness is intertwined because they often gather and 
communicate religious matters together, communicate in giving da'wah messages to us female peers who are veiled. Veiled women are very compact and avoid differences of opinion between themselves because in this group they prohibit it to talk about other problems and khalifa in preaching. They commit veiled sisters to wearing the veil, not only the concept of protecting women in the Koran and Hadiths but also the culture of piety which is implemented in everyday life.

We can interpret construction of the essence of identity which through signs of taste, belief, attitude and lifestyle. We consider identity to be both personal and social, which shows that "we are the same or different" from others. These signs should not be interpreted as something that is outlined permanently but as a form that can be changed and changed, and is related to various socio-cultural contexts and interests (A.A. Ngr Anom Kumbara, 2008).

By using the veil, the sisters feel that they have increased their faith in Allah SWT. As expressed, the STR of a student, for about 1 year of increasing the veil said that;

"I didn't understand before, I used to wear a headscarf only at the limit of my chest, but after I studied and studied, finally I was determined to find a big reward, so I changed myself to be better, to be perfect. The advantage of covering our faces in the world, Allah will come to us, because in this world we are already veiled, we only see our eyes, all are covered, the veil is long, so if we close in the world, Allah will come to us later. (Interview 13 June 2019)

The woman with the veil is objectification of the veil in social representation theory. They try to construct a coherent identity narrative in which the self-forms a developmental trajectory from the past to the predictable future. The obligation of a woman to wear a veil, the obligation to veil, is inherent in them, where veiled women believe that the way they wear the veil is an obligation that has been regulated by the Al-Qur'an and $\mathrm{Al} \mathrm{Hadith}$. In their belief in the obligation to veil, there is a value that they believe in, and they also believe that these values are absolute and absolute.

A value of belief and belief which becomes the basis for a person or group of people to choose their actions, or judge something meaningful for their lives. Veiled women are bound by a belief in the way they veil and it is a commitment to what they believe. Their commitment to the values inherent in the way they wear the hijab makes them think less about the 
efficiency of the hijab itself. This is evidenced by the way they wear the hijab which is usually considered less efficient in its use according to women who wear a fashionable headscarf. However, for veiled women, the way they wear the veil is considered more efficient in achieving the noble goals they have believed in. Perspectives or distinct patterns of thinking in seeing a value in achieving goals.

The rational mindset they use in understanding the veil sometimes makes them seem irrational. Because what they think is rational is not necessarily what other people think is rational. The mindset that they think is rational they have because of a firm commitment or understanding they have towards the existence of a value and purpose that is absolute for them. Their mindset or understanding in understanding religious knowledge makes them believe that Allah requires what is beneficial for them, both in this world and in the (Amalia et al., 2013). Things that encourage the creation of aspects of commitment cohesiveness, including: satisfaction, environment, group culture, group members' attitudes, relationships with fellow group members and group cohesiveness.

In this study focused on group cohesiveness factors. Mossholder, Bedeian and Armenakis (Gibson, et al., 2003) reported a relationship between the level of group cohesiveness and organizational commitment. The results showed that the level of group cohesiveness had a positive effect on employee commitment to the organization reduced work pressure and the tendency to leave work described which and increased work performance. We believe a group with high cohesiveness to have a high commitment to maintaining the group. This commitment to a small group scope will eventually develop into a broader commitment, namely a commitment to the organization, depending on how much the group has in common with the organization (Trihapsari \& Nashori, 2011).

The cohesiveness of veiled women in commitment as part of the element of social cohesiveness, as "group pride." as found in the results of research on group pride refers to the extent to which each member of the group shows the same feeling of liking the status or ideology that each group member supports or represents or for the common interest of being a group member. Group pride reinforces the construct as a team-level construct and is most relevant to group pride theory (Severt \& Estrada, 2015). Women with veils have confidence and their affective using the veil adds a new identity in themselves and must be implemented into daily activities as piety. Affective cohesion refers to the interpersonal and 
affective support that group members achieve and provide to one another (Severt \& Estrada, 2015).

\section{Aspects of Cohesiveness of Goal Achievement}

The strong desire of veiled women to join groups is because of the prestige that comes as part of group membership. The cohesive aspect of goal attainment motivates veiled women because of the perceived connection and relevance of the common goal. The cohesive purpose of veiled women's da'wah communication encouraged them to become better women. As stated by DIM, HDS, MS, and other informants, respectively, AT, NIV and SS, that:

"Our student friends, who we have are very inspiring for us to follow and keep wearing the veil, this is probably because we always chat, meet and exchange ideas we are like brothers with a high commitment to always convey the things. For our togetherness better.," (Interview 14 July 2019)

They conveyed the same thing that as women, they must remind each other of kindness. As one quote from the interview results:

"Our commitment (veiled women) must embrace each other and change their mindsets, we also realize that other women must also be. Should think that way. Maybe because they don't have the knowledge about the law to cover their genitals later. Second, maybe they just lack motivation so that in the future everything will be better”. (Interview 19 July 2019)

The cohesiveness aspect of veiled women for the achievement of goals results from their group integration in communicating da'wah. Cohesiveness for every veiled woman gets shared motivation and is committed to achieving the same goal. In this context, veiled women are a da'wah group in which in their daily da'wah activities they often engage in interactions with each other, such as reverence for women, eating together, studying together and worshiping together. This is a sense of community and shows cohesiveness within the group. In a group that has strong cohesiveness, of course, also has solid cooperation within the group. Researcher Mikalachki (1969) was one of the first researchers to explicitly identify and label elements of social cohesiveness, that social cohesion refers to the interpersonal bonds that exist between members (for example, 
The Cohesiveness of Veiled Women's Da'wah Communication Group

liking, attracting, and believing). Whereas the goal of cohesiveness refers to the joint commitment of members to a common goal (Severt \& Estrada, 2015).

The woman in the veil focuses on achieving her life goals for the afterlife. They live in this world only a means to the afterlife. Women who wear the veil are no longer struggling with matters of obligation for a woman, but to convey messages of da'wah communication, multiply the practice of the Prophet's Sunnah and raise the veil, Al-Quran and Hadiths are no longer to be questioned, but believed and implemented.

The conception in which the identity of a woman in a veil wants to show her identity as a Muslim woman who is a veiled Muslim woman who is a woman's nature, and knowledge of Sunnah Such as the research results which reveal that the concept of a veiled woman's mind is that they think about the real understanding of the veil, namely as protection and obedience to religion. Likewise, the concept of self-veiled Muslim women is understood by the community that they already understand religion, are more distant, and are polite. So that in the concept of society, veiled Muslim women greet each other, often use Arabic interludes, behave politely and understand the arguments (Amalia et al., 2013).

To be clearer about the cohesiveness aspect of dakwah communication, they show it in the following table form,

Table 1. Aspects of Cohesiveness in Veiled Women's Da'wah Communication

\begin{tabular}{|c|c|c|}
\hline No. & $\begin{array}{l}\text { Aspects of veiled women's } \\
\text { cohesiveness }\end{array}$ & Da'wah Communication \\
\hline 1. & $\begin{array}{c}\text { Aspects of Interpersonal } \\
\text { Communication Cohesiveness }\end{array}$ & $\begin{array}{c}\text { Participative } \& \text { interactive, messages of } \\
\text { da'wah to build relationships in groups, } \\
\text { and positive feedback. }\end{array}$ \\
\hline 2. & $\begin{array}{c}\text { Aspects of Committed } \\
\text { Cohesiveness }\end{array}$ & $\begin{array}{c}\text { A clear and accepted role for every veiled } \\
\text { woman }\end{array}$ \\
\hline 3. & $\begin{array}{c}\text { Aspects of Cohesiveness of Goal } \\
\text { Achievement }\end{array}$ & $\begin{array}{l}\text { The veiled woman's motivation is } \\
\text { activated based on the connection and } \\
\text { relevance of a common goal. }\end{array}$ \\
\hline
\end{tabular}

The cohesiveness of veiled women in group communication has several aspects of cohesiveness. The cohesiveness aspect of da'wah communication is in terms of high commitment with the group, dominated by cooperation, not competition, has objectives related to one another and 
under the development of time the goals planned increase, exchanges between group members that are binding and interest between them as relationships that are formed and strengthen the network of relationships in the group.

The theoretical view of cohesion as a multidimensional construct. Festinger (1950) proposes that the creativity of a group results from all the forces acting on members to remain in the group. These strengths depend on the attractiveness or disinterest in either the prestige of the group, the members of the group, or the activities in which the group is involved (Severt \& Estrada, 2015). Although it does not explicitly identify the cohesiveness dimension underlying a group.

The cohesive aspects of veiled women's da'wah communication were found to have the same pattern in seeking the science of devotion. They are in the veil conceptualized to continue to improve themselves, the perfection of understanding, one of which is by continuing to learn, whether from the experience of friends in the veil, books, formal education, joint studies, or from the recitations followed. It relates this to a strong desire to learn through da'wah communication. Da'wah communication is participatory, where they feel better when they feel part of an interactiveda'wah discussion and part of the group function. Da'wah messages confirm messages that help build a relational dimension among fellow veiled women in groups, and clear, organized, and relevant messages help construct dimensions of shared responsibility and generate positive, and relevant feedback contributing to their group climate.

Besides their individual participation, veiled women feel as if participation is managed equally in group communication and through an appropriate division of roles. A clear and accepted role to lead to satisfaction, veiled women also feel comfortable with and accept the role. The veiled woman's motivation is active through the perceived connection and relevance of a common goal. The consequences in carrying out the Shari'a will lead them to maintain their attitude and behavior. So basically the choice of veiled women in veiling they came not from coercion but from their self-awareness of their obligations as women who have to carry out Allah's orders and have good morals. They don't want to impose people's views. The three informants held firmly and wanted to make selfesteem the identity of the veiled Muslim woman istiqomah, the nature of women and the science of sunnah. 
The Cohesiveness of Veiled Women's Da'wah Communication Group

\section{CONCLUSION}

The cohesiveness of veiled women's da'wah communication includes aspects of interpersonal communication cohesiveness, aspects of committed cohesiveness, and cohesive aspects of achieving common goals. This aspect of cohesiveness focuses his life on life after death. Sami'na Wa ato'na. This also gives them a strong and sincere character. Da'wah communication cohesiveness to have a strong desire to learn together with Islam. Da'wah communication is participatory and interactive as part of a group function. Da'wah messages that help build a relational dimension among veiled women in groups, and clear, organized, and relevant messages help construct dimensions of shared responsibility and generate positive, and relevant feedback.

This makes this group more compact and familiar in preaching. Cohesivity that occurs in groups. The group cohesiveness is based on the similarity to preach collectively through the use of the veil in everyday life, as the purpose of life so that they are united in preaching efforts.

The results also indicate that the cohesiveness of the da'wah communication of veiled women is the possibility of implementing or developing research and suggestions for further research. Leads to groupthink symptoms that are seen when holding meetings to discuss various reasons for decision making.

\section{REFERENCES}

A.A. Ngr Anom Kumbara. (2008). Konstruksi Identitas Orang Sasak Di Lombok Timur Nusa Tenggara Barat, Humaniora, 20(3), 315-326. https://jurnal.ugm.ac.id/jurnal-humaniora/article/view/947

Ahmed, N., Amaya, C., Kunene, T., \& Thompson, J. (2012). Communication and Cohesion in Undergraduate Teams.

Amalia, P., Iskandar, S., Sos, H. S., \& Up, M. (2013). Konstruksi Identitas Muslimah Bercadar Identitas Contruktion Muslimah Of Cadar. Artikel, 1-12.

Burhanuddin, B. (2019). Membangun Pola Komunikasi Dakwah Sebagai Alternatif Mencegah Sikap Intoleransi Beragama, Dakwab: Jurnal Kajian Dakwah Dan Kemasyarakatan, 21(1), 19-42. https://doi.org/10.15408/dakwah.v21i1.11796

Effendy, D. I., \& Rustandi, D. (2020). The Identity Construction of Da'wah Leadership on Jama'ah Tabligh Movement, Ilmu Dakwab: Academic 


Journal for Homiletic Studies, 14(1), 145-162.

https://doi.org/10.15575/idajhs.v14i1.9210

Harrison, S. J., McAllister, D., \& Alder, G. S. (2003). Communication Media and Group Cohesion in Organizational Teams: An Analysis of Differences between Supervisors and Team Members, Journal of Interdisciplinary Business Studies, January 2012. https://www.researchgate.net/publication/262675364_Communic ation_Media_and_Group_Cohesion_in_Organizational_Teams_An _Analysis_of_Differences_Between_Supervisors_and_Team_Mem bers

Ikbar, I., Nurrahmi, F., \& Syam, H. M. (2019). Kohesivitas Pada Kelompok Jamaah Tabligh, Jurnal Komunikasi Global, 8(2), 258-270. https://doi.org/10.24815/jkg.v8i2.15266

Iman Iskandar. (2020). the Effect of Group Cohesiveness and Job Satisfaction on Productivity in Employees of Human Resources Development in the Ministry of Home Affairs, International Journal of Engineering Technologies and Management Research, 6(8), 57-62. https://doi.org/10.29121/ijetmr.v6.i8.2019.441

Jarvis, M. (2006). Personality characteristics and sporting behaviour. In Sport psychology: A student's handbook.

Jasperse, M., Ward, C., \& Jose, P. E. (2012). Identity, Perceived Religious Discrimination, and Psychological Well-Being in Muslim Immigrant Women, Applied Psychology, 61(2), 250-271. https://doi.org/10.1111/j.1464-0597.2011.00467.x

Kebaili, S., Zanina, N., \& Arfa, Y. (2015). Impact of Team Cohesion on performance among Tunisian Women Soccer Players, IOSR Journal of Sports and Physical Education, 2(5), 15-18. https://doi.org/10.9790/6737-0251518

Lintang Latri. (2016). Cadar, Media, dan Identitas Perempuan Muslim. 4(1), 64 75.

Maghfiroh, E. (2016). Komunikasi Dakwah; Dakwah Interaktif melalui Media Komunikasi, Dakwatuna: Jurnal Dakwah Dan Komunikasi Islam, 2(1), 34-48.

Nurjuman, H., Restu, U., \& Kususma, B. T. (2018). Konstruksi Islam sebagai Simbol Identitas melalui Representasi Perempuan Muslim pada Novel Religi, Ilmu Dakwab: Academic Journal for Homiletic Studies, 12(1), 61-81. https://doi.org/10.15575/idajhs.v12i1.1937

Nursalam, N., \& Syarifuddin, S. (2017). Persepsi Masyarakat Tentang 
The Cohesiveness of Veiled Women's Da'wah Communication Group

Perempuan Bercadar, Equilibrium: Jurnal Pendidikan, 3(1), 116-125. https://doi.org/10.26618/equilibrium.v3i1.519

Purnama, Y. (2011). Hukum Memakai Cadar dalam Pandangan 4 Madz̧hab. Muslim.or.Id. https://muslim.or.id/6207-hukum-memakai-cadardalam-pandangan-4-madzhab.html

Purwaningtyastuti, Wismanto, B., \& Suharsono, M. (2012). Kohesivitas Kelompok Ditinjau Dari Komitmen Terhadap Organisasi Dan Kelompok Pekerjaan, Kajian Ilmiah Psikologi, 1(2), 179-182. http://journal.unika.ac.id/index.php/pre/article/view/245

Puspanegara, V. (2016). Perilaku Komunikasi Perempuan Muslim Bercadar Di Kota Makassar (Studi Fenomenologi). http://digilib.unhas.ac.id/opac/detail-opac?id=23717

Qomaria, N., \& Musadieq, M. (2015). Peranan Kohesivitas Kelompok Untuk Menciptakan Lingkungan Kerja Yang Kondusif (Studi Pada Pt. Panca Mitra Multi Perdana Situbondo), Jurnal Administrasi Bisnis S1 Universitas Brawijaya, 29(1), 77-85.

Rahman, A. F., \& Syafiq, M. (2017). Motivasi, Stigma dan Coping Stigma pada Perempuan Bercadar, Jurnal Psikologi Teori Dan Terapan, 7(2), 103. https://doi.org/10.26740/jptt.v7n2.p103-115

Retno Ristiasih Utami. (2016). Kohesifitas Karyawan Ditinjau dari Gender dan Bagian Kerja. Peran Budaya Organisasi Terhadap Efektivitas Dan Efisiensi Organisasi, 61-73.

Sari, Y., Erlyani, N., \& Akbar, S. N. (2017). Peranan Komunikasi Interpersonal Terhadap Kohesivitas Kelompok Pada Komunitas Motor Di Banjarbaru, Jurnal Ecopsy, 3(2). https://doi.org/10.20527/ecopsy.v3i2.2658

Severt, J. B., \& Estrada, A. X. (2015). On the function and structure of group cohesion, Research on Managing Groups and Teams, 17(November 2015), 3-24. https://doi.org/10.1108/S1534-085620150000017002

Sudirman, M. (2019). Cadar Bagi Wanita Muslimah (Suatu Kajian Perspektif Sejarah), DIKTUM: Jurnal Syariah Dan Hukum, 17(1), 4964.

Trihapsari, V. R., \& Nashori, F. (2011). Kohesivitas Kelompok Dan Komitmen Organisasi Pada Financial Advisor Asuransi "X" Yogyakarta, Proyeksi, 6(2), 12. https://doi.org/10.30659/p.6.2.12-20 
